\title{
PERSONALIZED LEARNING DAN MULTIMEDIA BERBASIS KOMPUTER MASIH PERLUKAH GURU?
}

\author{
Mufdalifah \\ SMAN 2 Sampang \\ JL.Mangkubumi 36 Sampang, Madura Jawa Timur 69215 \\ move.spg@gmail.com
}

\begin{abstract}
ABSTRAK
Sejak berkembangnya teknologi infomasi dan komunikasi, banyak klaim dari para teknolog pembelajaran bahwa peran guru akan semakin berkurang dan bahkan berakhir, namun klaim- klaim tersebut sampai saat ini tidak terbukti meskipun teknologi multimedia semakin canggih. Di samping itu model-model pembelajaran juga memberikan dukungan terhadap bentuk-bentuk pembelajaran yang semakin individual, salah satunya adalah personilezed learning yang memberi kesempatan setiap siswa untuk maju dan berkembang menurut kecepatan dan kemampuan masing-masing siswa dalam penguasaan materi dan belajar sesuai dengan keinginan dan kemampuannya masing-masing. Dengan demikian, gabungan antara kecanggihan teknologi multimedia interaktif dan meodel pembelajaran individu semakin menguatkan asumsi bahwa peran guru akan berakhir, oleh karenanya tulisan ini ingin mengakaji secara teoritik apakah kekhawatiran tersebut memang relevan secara teoritik praktik.
\end{abstract}

Kata kunci: personalized learning, multimedia berbasis komputer, peran guru

\section{PERSONALIZED LEARNING AND MULTIMEDIA BASED ON COMPUTER IS TEACHER STILL NEEDED?}

\begin{abstract}
Since the development of information and communication technologies, many of the claims of the instructional technologist that the role of the teacher will be reduced and even ended, but the claims are so far not proven despite increasingly sophisticated multimedia technology. In addition, learning models also provide support to other forms of learning are increasingly individualized, one of which is personilezed learning that allows each student to progress and evolve according to the speed and abilities of each student in the mastery of the material and learning in accordance with the wishes and ability of each. Thus, a combination of technological sophistication of interactive multimedia and individual learning model reinforce the assumption that the role of the teacher will end, therefore, this paper wants to analise theoretically whether these concerns are relevant theoretical practice.
\end{abstract}

Keywords: personalized learning, computer-based multimedia, the role of the teacher 


\section{PENDAHULUAN}

Sejak era tahun 60-an, Fred S Kellersudah menulis dalam tentang profesi guru. Dia mengritik penerapan metode-metode pembelajaran yang kurang menarik perhatian siswa, bahkan menghilangkan hak siswa untuk belajar. Dalam paragraf awal yang cukup kontroversial, dikatakan: "when I was a boy, and school 'let out' for the summer, we used to celebrate our freedom from educational control by chanting: good-bye scholars, good-bye school, good-bye teacher, darned old fool!"(Keller, 1968).

Kritik-kritik terhadap sistem pembelajaran yang berpusat pada guru memicu berkembangnya penelitian tentang model-model pembelajaran humanis, yaitu pembelajran yang memberi tumpuan kepada apa yang berlaku dalam diri seorang individu seperti perasaan atau emosi. Salah satu model yang menarik adalahPersonalized Learning, yaitu pembelajaran yang dikembangkan untuk memenuhi kebutuhan dan aspirasi perorangan. Menurut Sahabuddin \& Ali (2013) cara belajar ini dapat berupa mentoring dalam kelompok kecil hingga belajar sendiri menggunakan teknologi modern seperti web-web edukasi.Cara ini sering di sebut belajar "kapan saja, dimana saja".Namun untuk mencapai hasil yang maksimal, perlu diciptakannya suatu keselarasan antara pengajar dan teknologi yang digunakan.

Berkaitan dengan penggunaan teknologi sebagai pendukung Personalized Learning, dewasa ini kemajuan teknologi informasi dan komunikasi memberikan ruang yang cukup bagi siapapununtuk melakukan improvisasi dalam penggunaanya. Media sebagai jembatan yang dapat menyampaikan pesan-pesan edukatif sudah dapat dikemas dalam bentukinteraktif yang memungkinkan adanya gambar dan suara yang sudah diprogram dan dapat digunakan sekaligus atau disebut juga dengan istilah multimedia (Mayer 2001). Keunggulannya terletak pada penggunaan media teks, audio, grafik, gambar diam dan gambar gerak dapat dikombinasikan dalam satu sistem yang mudah.

Perkembangan metode pembalajaran yang mengarah pada pembelajan secara individu dan berkembangan multimedia berbasis komputer yang semakin tanpa batas, semakin menjadi ancaman bagi sistem pembelajaran klasikal. Hal tersebut sudah diklaim oleh Thomas A. Edison pada era 60-anbahwa "the motion picture is destined to revolutionize our educational system and that in a few years it will supplant...the use of textbooks" (Cuban, 1986 dalam Mayer dan Moreno, 2007). Selanjutnya pada era 70 -an program permainan game pembelajaran berbantuan komputer juga dianggap sebagai gelombang baru yang mengkhawatirkan masa depan pembelajaran-meskipunsampai sejauh ini klaim-klaim tersebut tidak pernah terbuktiartinyapembelajaran yang berbasis multimedia ternyata tidak lebih ekfektif dibandingkan pembelajaran berbasis guru (Cognition and Technology Group at Vanderbilt, 1996 dalam Mayer dan Moreno, 2007), namun demikian bukan berarti klaim tersebut sudah gugur.

Menurut Mayer dan Moreno (2007) kegagalan media interaktif menggantikan peran 
guru sebenarnya disebabkan oleh kurangnya dukungan teoretik yang berbasis riset.Artinya, jika saja penelitian-penelitian tentang pendekatan pembelajaran berbasis pemanfaatan multimedia semakin berkembang dan menghasilkan teori yang kokoh, maka sangat mungkinungkapan Keller (1968) yang menyatakan: "good-bye scholars, good-bye school, good-bye teacher",betul-betul menjadi kenyataan. Oleh karena itu, tulisan ini mencoba menganalisis secara teoretik berdasarkan fenomena kekinian tentang perkembangan personalized learning dan multimedia berbasis komputer untuk mengkaji efetifitasnya beserta kemungkinan dampak bagi peran guru dalam kegiatan pembelajaran.

\section{PEMBAHASAN}

\section{Personalized Learning}

$$
\text { Green, dkk., }
$$
berpendapat,personalized learning adalah pembelajaran fleksibel yang memungkinkan siswa berinteraksi dengan materi pembelajaran yang sesuai dengan kebutuhan mereka (dalam Sahabuddin \& Ali, 2013).Sistem ini memberi kesempatan setiap siswa untuk maju dan berkembang menurut kecepatan dan kemampuan masing-masing siswa dalam penguasaan materi. Menurut Clarke (2003) jika pebelajar ditempatkan dalam kondisi lingkungan belajar personalized, mereka akan lebih efektif dalam belajar dengan menggunakan pengetahuannya dan berjuang untuk menemukan informasi lebih banyak lagi (dalam Sahabuddin \& Ali).
Dalam menciptakan lingkungan pembelajaran personalized, diperlukan beberapa persyaratan yang harus dipenuhi, yairtu: (1) adanya penguasaan yang sempurna bagi setiap unit pelajaran sebelum maju ke unit pelajaran berikutnya, (2) metode cermah dan demonstrasi sebagai alat untuk memberi motivasi kepada siswa, (3) komunikasi ditekankan pada penggunaan materi pembelajaran tertulis dalam bentuk programa, (4) menggunakan sistem pemberian tes secara berulang-ulang untuk memberikan penilian secara cepat dan sebagai umpan balik bagi pemberian bantuan kepada pebelajar yang membutuhkan, dan (5) menggunakan siswa tutor yang pandai untuk memberi bimbingan belajar kepada yang kurang atau lemah (Adelman \& Taylor, 2012).

Pada hakikatnya, personalized learning adalah bentuk pembelajaran yang lebih memberdayakan pebelajar (student centered).Mereka tidak lagi menjadi objek yang harus mengikuti kemauan guru melaikan dapat menentukan sendiri bagaimana seharusnya melakukan pembejaran terhadap dirinya sendiri dan menyelesaikan perkerjaannya dengan baik (Etes, 2004).Personalized learningdalam pelaksanaannya mencerminkan sistem pembelajaran individual yang berpusat pada kegiatan siswa (student centerd lerning), dengan beberapa modifikasi dan sangat memperhatikan perbedaan antara individu pebelajar. Sistem pembelajaranpersonaliazed menggunakan semacam program yang sudah dirancang dengan melibatkan e-learning dan jejaring sosial seperti: blogs, facebook, twitter, dll., (Mcloughlin \& 
Lee, 2010 dalam Sahabuddin \& Ali, 2013).Dengan demikian dapat disimpulkan bahwa dalam menerapkan personalized learningdibutuhkan infrastruktur sarana dan prasarana pendukung yang memadai.

\section{Multimedia Learning}

Peran multimedia dalam pembelajaran menurut Mayer (2001) adalah sebagai pendukung terselenggaranya proses komunikasi interaktif antara guru, peserta didik, dan bahan belajar. Istilah yang biasa dikenal dalam dunia multimedia pembelajaran adalah Computer Asisted Instruction (CAI)atau dalam istilah yang sudah diterjemahkan disebut sebagai "Pembelajaran Berbantuan Komputer (PBK)". Istilah ini merujuk kepada semua software pendidikan yang diakses melalui komputer dimana pengguna dapat berinteraksi dengan semua komponen, baik gambar, tulisan, warna, dan suara.

Menurut Taylor (dalam Tamir, 1986), proses belajar berbantuan komputer dapat dibagi menjadi tiga bagian yaitu: 1) Sebagai toolkarena dapat menyajikan informasi yang dapat digunakanberulang-ulang sesuai keperluan dan kecepatan pebelajar. 2) Sebagai tutor digunakan untuk menampilkan, menjelaskan konsep dan ide di mana pebelajar dapat berinteraksi dengan komputer ketika menampilkan suatu informasi, menjawab pertanyaan atau masalah yang sesuai dengan informasi,mengevaluasi jawaban pebelajar dan menentukan apakah yang harus diperbuat pebelajar selanjutnya. 3) Sebagai tutee digunakan untuk mengajar komputer misalnya dengan bahasa program (LOGO, Basic, Pascaldan sebagainya). Sedangkan Merril, dkk., (1996) berpendapat bahwa dalamproses belajar dan pembelajaran berbantuan komputer pada umumnya adalah: (1) komputer menyajikan beberapa informasi, (2) pebelajar diminta untuk merespon pertanyaan atau masalah yang berkaitandengan informasi, (3) komputer mengevaluasi respon pebelajar menurut kriteria khusus, dan (4) komputer menentukan apa yang selanjutnya dikerjakan berdasarkan evaluasi respon tersebut.

Perkembangan media pembejaran dewasa ini memungkinkan pebelajar melakukan interaksi secara aktif dengan media. Sedangkan media interaktif berbasis komputer dapat menciptakan lingkungan belajar multimedia dengan sistem penyajian pembelajaran; visual, suara, dan materi video disajikan dengan kontrol komputer, sehingga pebelajar tidak hanya dapat mendengar dan melihat gambar dan suara, tetapi juga memberi respon aktif.Penggunaan media interaktif memiliki karakteristik penting bahwa, pebelajar tidak memperhatikan media atau objek saja, melainkan juga dituntut untuk berinteraksi selama mengikuti belajar.Sedikitnya ada tiga macam interaksi, yaitu (1) pebelajar berinteraksi dengan sebuah program, (2) pebelajar berinteraksi dengan mesin, dan (3) mengatur interaksi antara pebelajar secara teratur tapi tidak terprogram.

\section{Hakikat Pembelajaran}

Belajar merupakan seperangkat proses yang bersifat internal bagi setiap pribadi yang 
merupakan hasil transformasi rangsangan yang berasal dari peristiwa eksternal atau kondisi di lingkungan pribadi yang bersangkutan. Agar kondisi eksternal itu lebih bermakna maka pembelajaran harus diorganisasikan dalam urutan peristiwa (Gagne, 1977dalam Miarso, 2004).Menurut Degeng (2013) pengorganisasian tersebut merupakan tugas dari ilmu pembelajaran dalam mengatur strategi yang dapat mendorong prakarsa dalam memudahkan proses belajar mengajar.Proses belajar mengajar sendiri merupakan fenomena kompleks yang melibatkan setiap kata, pikiran, tindakan, dan juga asosiasi.

Lozanov (1978), menyatakan sampai sejauh mana seorang guru mampu mengubah lingkungan, presentasi, dan rancangan pengajarannya, maka sejauh itu pula proses belajar mengajar berlangsung (dalam DePorter, 2002: 3). Hal tersebut menunjukkan bahwa dalam pembelajaran diharapkan dapat mengarahkan perhatian pebelajar ke dalam nuansa proses pembelajaran yang bermakna. Menurut Walberg (1997) dalam DePorter (2002: 23) untuk menciptakan pembelajaran yang baik, diperlukan adanya ikatan emosional dengan pebelajar, yaitu dengan menciptakan kesenangan dalam belajar, menjalin hubungan dan menyingkirkan ancaman.

Berkaitan dengan belajar dan pembelajaran, terdapat perbedaan prinsip antara teori belajar dengan teori pembelajaran. Teori belajar bersifat deskriptif, karena tujuan utamanya memeriksa proses belajar, sedangkan teori pembelajaran adalah preskriptif, karena tujuan utamanya menetapkan metode pembelajaran yang optimal (Bruner dalam Degeng, 2013). Teori belajar fokus kepada bagaimana pebelajar belajar, sehingga berhubungan dengan variabel-variabel yang menentukan hasil belajar.Kondisi dan metode pembelajaran merupakan variabel bebas sedangkan hasil pembelajaran sebagai variabel tergantung.Dengan demikian, dalam pengembangan teori belajar, variabel yang diamati adalah hasil belajar.

Dalam pengembangan teori belajar, hasil yang diamati adalah hasil pembelajaran nyata (actual outcomes), yaitu hasil pembelajaran yang mungkin muncul, dan bisa jadi bukan merupakan hasil pembelajaran yang dinginkan. Oleh karena teori belajar adalah deskriptif, maka menggunakan struktur logis "Jika ...., maka ....." (Landa dalam Degeng, 2013). Sebagai contoh,"Jika materi pelajaran (suatu kondisi) diorganisasi dengan menggunakan model elaborasi (suatu metode) maka perolehan belajar dan retensi (suatu hasil) akan meningkat". Dalam proposisi teori belajar tersebut, model pengorganisasian pembelajaran ditetapkan sebagai perlakuan, di bawah kondisi karakteristik isi pelajaran, untuk memerikan perubahan unjuk kerja (actual outcomes), berupa peningkatan perolehan belajar dan retensi.

Teori pembelajaran adalah goal oriented, artinya, teori pembelajaran dimaksudkan untuk mencapai tujuan (Reigeluth, 1983). Oleh karena itu, variabel yang diamati dalam teori pembelajaran adalah metode yang optimal untuk mencapai tujuan.Hasil pembelajaran yang 
diamati dalam pengembangan teori pembelajaran adalah hasil pembelajaran yang diinginkan (desired outcomes) yang telah ditetapkan lebih dulu.Karananya teori pembelajaran berisi seperangkat preskriptif untuk mengoptimalkan hasil pembelajaran yang diinginkan di bawah kondisi tertentu.

Dalam proposisi teori pembelajaran, peningkatan perolehan belajar dan retensi ditetapkan sebagai hasil pembelajaran yang diinginkan dan model elaborasi yang merupakan salah satu model untuk mengorganisasi materi pelajaran, dijadikan metode yang optimal untuk mencapai hasil pembelajaran yang diinginkan. Dalam teori pembelajaran harus terdapat variabel metode pembelajaran untuk mengungkapkan hubungan antara kegiatan pembelajaran dengan proses psikologis dalam diri peserta didik. Jadi, dalam teori pembelajaran, terdapat preskripsi tindakan belajar yang harus dilakukan agar proses psikologis dapat terjadi.

Secara garis besar, teori belajar dikelompokkan menjadi dua, yaitu teori sebelum abad ke-20 dan teori belajar abad ke-20.Yang termasuk teori belajar sebelum abad ke-20, yaitu teori disiplin mental, teori pengembangan alamiah, dan teori apersepsi.Teori belajar sebelum abad ke-20 dikembangkan berdasarkan pemikiran filosofis atau spekulatif, tanpa dilandasi eksperimen. Sedangkan teori belajar abad ke-20, dibagi menjadi dua macam, yaitu teori belajar perilaku (behavioristik) dan teori belajar Gestalt-field. Teori belajar perilaku (behavioristik), berlandaskan kepada stimulusrespons sedangkan teori belajar Gestalt-field, berlandaskan kepada segi kognitif (Hergenhahn \& Olson, 2008).

Belajar dapat diartikan sebagai proses perubahan perilaku akibat interaksi individu dengan lingkungan meskipun pada dirinya hanya ada perubahan dalam kecenderungan perilaku(Hergenhahn \& Olson, 2008). Kecenderungan perubahan perilaku mencakup pengetahuan, pemahaman, keterampilan, sikap yang dapat diamati maupun tidak dapat diamati.Perilaku yang dapat diamati disebut behavioral performancesedangkan yang tidak dapat diamati disebutbehavioral tendency.Terdapat perbedaan yang mendasar antara perilaku hasil belajar dengan yang terjadi secara kebetulan. Seseorang yang secara kebetulan dapat melakukan sesuatu, tidak dapat mengulangi perbuatan itu dengan hasil yang sama. Sedangkan seseorang dapat melakukan sesuatu karena hasil belajar dapat melakukkannya secara berulang-ulang dengan hasil yang sama.

\section{Personalized Learning, Multimedia Learning dan Peran Guru}

Setelah mencermati pendekatan personalized learning dan multimedia learning, maka pertanyaanya, "masih perlukah guru?". Untuk menjawab pertanyaan tersebut, perlu diperhatikan beberapa hal yang menjadi kelebihan dan kekurangan multimedia yang berbasis komputer sehubungan dengan pembelajan individual dan hakikat pembelajaran. Menurut Schramm (1984) beberapa hal yang menjadi kelemahan dalam pembelajaran berbasis komputer adalah: (1) diperlukan 
pengetahuan dan keterampilan khusus tentang computer, (2) ragam model komputer (hardware) sering menyebabkan program (software) yang tersedia untuk satu model tidak cososk dengan model lainnya, (3) program yang tersedia masih belum memperhitungkan kreativitas pebelajar, dan (4) komputer hanya akan efektif bila digunakan oleh satu orang atau beberapa orang dalam kelompok kecil, sedangkanuntuk kelompok besar diperlukan tambahan peralatan lain yang mampu memproyeksikan pesan-pesan di monitor ke layar lebih lebar.

Di samping terdapat kelemahan multimedia berbasis komputer, beberapa faktor yang dapat memengaruhi keberhasilan pembelajaran berbantuan komputer. Hasil penelitian Arsyad (2010) menemukan, antara lain: (1)belajar harus menyenangkan, program permainan harus menyajikan tujuan yang hasilnya tidak menentu, (2)interaktivitas, yaitu dukungan komputer yang dinamis, dukungan sosial yang dinamis, aktif dan interaktif, (3)saat berlatih harus memotivasi, cocok, dan tersedia feedback, dan (4)menuntun dan melatih pebelajar secarainformal.

Menggunakan dan memanfaatkan perangkat teknologi komputer merupakan salah satu pendukung dari pembelajaran yang berbasis individu tanpa menghilangkan peran guru di dalamnya. Ketatnya sarat-sarat yang dapat menyebabkan keberhasilan pembelajaran individu berbantuan multimedia interaktif seperti yang ditemukan Arsyad (2010) adalah bukti bahwa peran guru masih sangat signifikan.
Dalam pelaksanaanya, guru menjadi fasilitator yang aktif dalam merencanakan, melaksanakan dan mengevaluasi hasil pembelajaran. Tanpa perencanaan, pelaksanaan dan evaluasi maka kegiatan belum disebut sebagai pembelajaran, atau yang disebut pengorganisasian pembelajaran (Degeng, 2013). Menurut (Reigeluth, 1983) pembelajaran adalah goal oriented, artinyapembelajaran dimaksudkan untuk mencapai tujuan. Oleh karena itu, hasil pembelajaran yang diamati dalam pembelajaran adalah hasil pembelajaran yang diinginkan (desired outcomes) yang telah ditetapkan lebih dulu.

\section{KESIMPULAN}

Cara belajar personalized dengan memanfaatkan multimedia berbasis komputer tidak berarti menghilangkan peran pengajar, tetapi membantu meningkatkan efektifitas proses pengajaran dengan menggunakan fasilitasfasilitas pendukung yang memungkinkan. Dengan menggunakan teknologi modern, pengajar dapat memperoleh data performa siswa dan mendeteksi minat dan kelemahan para pelajar lebih cepat. Pengajar juga akan terbebas dari paperwork sehingga dapat meluangkan waktu untuk mengajar dengan pendekatan yang lebih personal. Hal tersebut memberikan manfaat secara praktis dalam pelaksaan dan efisiensi waktu yang cukup sehingga memungkinkan pebelajar meningkatkan capaian materi lebih cepat dari pembelajaran tradisional. 


\section{DAFTAR PUSTAKA}

Arsyad, Azhar (2010) Media Pembelajaran. Jakarta. Rajawali Pers.

Degeng, N. S. (2013) Ilmu Pembelajaran Klasifikasi Variabel untuk Pengembangan Teori dan Penelitian. Bandung: Kalam Hidup.

DePorter, B. (2002) Quantum Teaching: Memraktikkan Quantum Learning di Ruang Ruang Kelas. Terjemahan oleh Ary Nilandari. Bandung: Kaifa.

Etes, C.A. (2004) Promoting Student Centered Learning in Experiental Education. Journal of Experiental Education. 27 (2). 141-160

Hergenhahn, B.R. \& Olson, Mattew, H. (2008)Theories of Learning. Edisi Ketujuh. Terjemahan oleh Tri Wibowo B.S. 2010. Jakarta: Kencana Prenada Media Group.

Keller, F.S. (1968) Good-bye Teacher. Journal of Applied Behavior Analysis. 1, 79-89

Mayer, R. E. (2001) Multimedia learning.Cambridge: Cambridge University Press.

Mayer, R. E., \& Moreno, R. (2007). A Cognitive Theory of Multimedia Learning: Implications for Design Principles. (online).
Merril P., Hammons K., Vincetn B., Reynolds P., Christensen L., Tolman M. (1996) Computers in Educational. Third Edition. New Jersey: Merrill Prentice Hall.

Miarso, Yusufhadi. (2004) Menyemai Benih Teknologi Pendidikan. Jakarta: Prenada Media.

Reigeluth, Charles M (1983) Intructional Design Theories and Models. Laurence Erlbaum Associates: New Jersey.

Sahabuddin, N.A. \& Ali, M.B. (2013) Personalized learning and style among upper secondary school students.Procedia-Social and Behavioral Sciences 103. 710-716

Tamir, P. (1986) Current and Potential Uses of Microcomputers in Science Education. Journal of Compters in Mathematics and Science Teachng. Winter 1986.

Wilbur, Schramm (1984)Media Besar dan Media Kecil; Alat dan Teknologi untuk Pendidikan, alih bahasa oleh Agafur, M.Sc. IKIP Semarang Press. 